\section{Perancangan dan Pengolahan Air Rawa Asin Mandiri di Desa Muara Halayung, Kabupaten Banjar Kalimantan Selatan}

\author{
Muthia Elma ${ }^{1,2}$
}

\author{
1 Program Studi Teknik Kimia, Fakultas Teknik, Universitas \\ Lambung Mangkurat (ULM) \\ ${ }^{2}$ Materials and Membranes Research Group (M²ReG), \\ Lambung Mangkurat University, Jl. A. Yani KM 36, \\ Banjarbaru, South Kalimantan 70714
}

melma@ulm.ac.id

\section{Pendahuluan}

Kelangkaan air merupakan permasalahan momok yang tidak pernah terselesaikan seiring bertambahnya populasi manusia di muka bumi ini terutama di daerah pedesaan. Pengolahan air secara sederhana untuk penyediaan air bersih merupakan kegiatan yang sangat dibutuhkan masyarakat seperti di Desa Muara Halayung. Kualitas sumber air yang buruk memaksa masyarakat untuk membeli air bersih dengan harga yang tidak murah. Terlebih lagi saat musim kemarau air menjadi asin akibat intrusi air laut saat pasang maksimum (Mariana \& Mahbub, 2015). Air rawa asin di Desa Muara Halayung bahkan mendekati salinitas air laut. Kualitas air rawa yang mengandung salinitas tinggi serta banyaknya kandungan bahan organik dapat menyebabkan warna, wasa dan bau pada air sehingga tidak layak untuk dikonsumsi (Matilainen et al., 2010). Pengolahan konvensional menggunakan koagulasiflokulasi dan filtrasi merupakan salah satu metode pengolahan sederhana yang dapat diaplikasikan di lingkungan masyarakat karena mudah untuk diaplikasikan.

Koagulasi-flokulasi memiliki kemampuan tinggi untuk menyisihkan konsentrasi bahan organik yang tinggi (Zhao et al., 2014, Pivokonsky et al., 2015, Jarvis et al., 2012). Alumunium sulfat atau tawas biasa digunakan pada tahap ini dikarenakan harganya yang murah (Maheshwari, 2006). Kemampuan tawas terbukti dapat menghilangkan warna, kandungan besi, dan substansi organik (Mahmud et al., 2012). Akan tetapi tidak efektif digunakan untuk menyisihkan Total Dissolved Solid (TDS) (Naswir, 2015). Filtrasi dapat digunakan untuk menurunkan TDS akibat flok dan
Desa Muara Halayung yang terletak di Kecamatan Beruntung Baru, Kabupaten Banjar memiliki permasalahan penyediaan air bersih. Lokasi desa yang sulit diakses menyebabkan belum terpasangnya distribusi air bersih dari Perusahaan Daerah Air Minum (PDAM). Selain itu air yang digunakan untuk keperluan sehari-hari mengalami instrusi air laut sehingga tidak layak untuk digunakan. Tujuan proyek ini adalah merancang dan menyediakan instalasi filtrasi air rawa asin mandiri sebagai upaya membantu warga mendapatkan air yang layak. Alat filtrasi dipasang dengan lapisan material berupa kerikil, ijuk, arang dan zeolite kapasitas tandon mencapai $500 \mathrm{~L}$. Hasil menunjukkan air olahan dari air rawa asin berhasil memenuhi baku mutu TDS, dan $\mathrm{pH}$ menurut PERMENKES No 492 Tahun 2010 serta berhasil menyisihkan garam.

Kata kunci: Air rawa asin, alat filtrasi, pengolahan air rawa asin

Diajukan: 31 Mei 2020

Direvisi: 10 Juni 2020

Diterima:15 Juni 2020

Dipublikasikan online: 17 Juni 2020

partikel yang mengendap selama proses koagulasi dan flokulasi. Pengolahan lanjutan yang cukup sederhana dan mampu menghilangkan partikel tersuspensi dan konsentrasi garam adalah filtrasi (EPA, 1995).

Filtrasi dengan beberapa lapisan sehingga memiliki pori yang selektif terhadap partikel-partikel terlarut (TDS). Terlebih dalam kasus ini, modifikasi dilakukan pada penggunaan material filter. Pada filter ini, digunakan bahan utama yaitu pasir zeolit yang berperan dalam menahan garam untuk ikut ke air olahan. Zeolit banyak digunakan pada berbagai macam aplikasi. Zeolite alami sebagai ion-exchange dan bahan sorbent untuk menyisihkan besi (Al-Anber \& Al-Anber, 2008). Penelitian Widiastuti, Wu, Ang, and Zhang (2011) melakukan penyisihan ammonium dengan zeolite pada grey water. Namun belum terdapat penelitian mengenai kemampuan zeolit sebagai material filter dalam proses filtrasi air rawa asin.

Pemilihan dan kemampuan bahan sebagai lapisan filter menjadi pertimbangan untuk menyisihkan air yang akan diolah. Penelitian Abhijeet (2014) menggunakan bahan yang mudah didapat dan ramah lingkungan digunakan sebagai lapisan filter berhasil menyisihkan kandungan besi. Selain itu penyisihan kandungan garam $\mathrm{NaCl}$ juga dapat dilakukan menggunakan zeolit. Zeolit menyisihkan ion garam dengan cara menukarnya dengan kalsium, yang kemudian menurunkan kandungan ion $\mathrm{Na}^{+}$(Santiago et al., 2016).

Proyek ini dilakukan dengan membangun instalasi alat filtrasi air rawa asin mandiri yang disingkat menjadi ASA RAMI. Alat ini diterapkan di desa Muara Halayung, kecamatan Beruntung Baru, Kabupaten Banjar, Kalsel. Sosialisasi pembuatan alat juga dilakukan untuk warga di sekitar. Masyarakat diharapkan dapat mengetahui

Cara mensitasi artikel ini:

Elma, M. (2020) Perancangan dan Pengolahan Air Rawa Asin Mandiri di Desa Muara Halayung, Kabupaten Banjar Kalimantan Selatan. Buletin Profesi Insinyur 3(1) 023-028 
penggunaan air bersih yang tepat dan sekaligus mampu menyediakan air bersih sendiri untuk skala rumah tangga dengan metode yang sederhana.

\section{Metode}

\section{Karakterisasi air rawa asin}

Sampel air rawa asin diambil di Kabupaten Banjar. Total dissolved solid (TDS) dan konnduktivitas diukur menggunakan OHAUS Conductivity Starter 300C. Sedangkan $\mathrm{pH}$ diukur menggunakan $\mathrm{pH}$ meter.

\section{Koagulasi-flokulasi}

Melakukan proses koagulasi air rawa asin dengan dengan alum sulfat. Lalu, diaduk sebentar, kemudian dilanjutkan proses sedimentasi (diendapkan) selama 20 menit (Mahmud \& Mu'min, 2011).

\section{Filtrasi}

Alat seperti Gambar 1

- Layer 1 : kerikil besar dengan ukuran (diameter $~ 3$ $\mathrm{cm})$, dengan ketebalan $15 \mathrm{~cm}$.

-Layer 2 : ijuk dengan ketebalan $6 \mathrm{~cm}$

-Layer 3 : arang dengan ketebalan $24 \mathrm{~cm}$

-Layer 4 : kerikil kecil (diameter $\sim 1 \mathrm{~cm}$ ), tebal $12 \mathrm{~cm}$

-Layer 5 : zeolite dengan ketebalan $18-25 \mathrm{~cm}$

-Layer 6 : kerikil kecil (diameter $\sim 1 \mathrm{~cm}$ ), tebal $12 \mathrm{~cm}$.

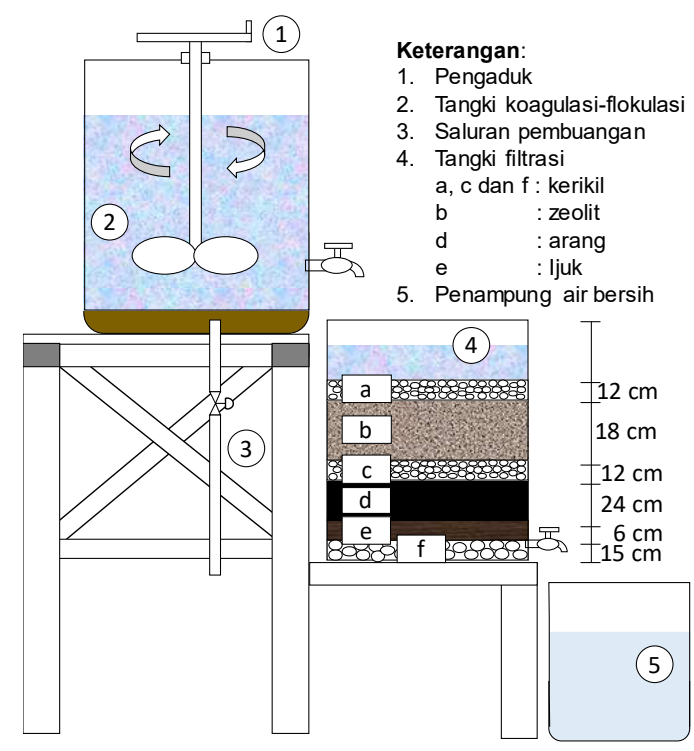

Gambar 1 Susunan material filter pada proses filtrasi

\section{Sosialisasi}

Sosialisasi dilakukan pada 1 kali pertemuan sekaligus demonstrasi cara mengolah air skala rumah tangga.

\section{Hasil Kerja}

\section{Karakterisasi air rawa asin}

Karakterisasi air sebelum diolah dapat dilihat pada Tabel 1
Table 1. Karakteristik air rawa asin

\begin{tabular}{lccc}
\hline Parameter & Satuan & $\begin{array}{c}\text { Air rawa } \\
\text { sebelum } \\
\text { diolah }\end{array}$ & Baku mutu \\
\hline TDS & $\mathrm{g} / \mathrm{L}$ & 6,64 & 1 \\
$\mathrm{pH}$ & - & 6,41 & $6.5-8.5$ \\
Konduktivitas & $\mathrm{mS} /$ & 13,27 & - \\
\hline
\end{tabular}

Karakteristik air rawa asin yang diambil di Kabupaten Banjar memliki pH rendah yang membuktikan air bersifat asam dan tidak layak konsumsi. Akan tetapi untuk TDS dan konduktivitas menunjukkan angka tinggi. TDS berhubungan langsung dengan konduktivitas, semakin tinggi TDS maka konduktivitas juga semakin tinggi. TDS sendiri mendeskripsikan bahan organik kecil dan garam inorganik di dalam air (Islam et al., 2017). Berdasarkan tabel 1 tersebut air rawa asin memiliki pH dan TDS belum memenuhi Permenkes No.32 Tahun 2017 sebagai air yang dapat digunakan untuk keperluan higiene sanitasi. Kandungan konduktivitas air rawa juga lebih tinggi dibandingkan air laut yang hanya memiliki nilai konduktivitas sekitar $\sim 43 \mathrm{mS} . \mathrm{cm}^{-1}$ (Bacon et al., 2007). Menunjukkan bahwa telah terjadi instrusi air laut ke dalam badan air rawa.

Pengaruh Dosis Kapur Terhadap TDS, pH dan konduktivitas

Pengaturan nilai $\mathrm{pH}$ air rawa asin dilakukan dengan menambahkan kapur sebelum proses koagulasi-flokulasi. Penelitian Duan et al. (2012) melaporkan bahwa penambahan $\mathrm{Ca}(\mathrm{OH})_{2}$ memberikan pengaruh terhadap nilai pH air. Gambar 2 menunjukkan bahwa semakin besar penambahan dosis kapur maka nilai pH juga akan semakin meningkat. Hasil ini sesuai dengan penelitian sebelumnya yang menyebutkan bahwa peningkatan nilai $\mathrm{pH}$ dapat terjadi akibat ion $\mathrm{Ca}^{2+}$ dan $\mathrm{OH}^{-}$mengalami pelarutan didalam air (Kilic et al., 2016, Othman et al., 2017). Penambahan kapur sebagai proses netralisasi bekerja efektif untuk mengatur nilai $\mathrm{pH}$ air.

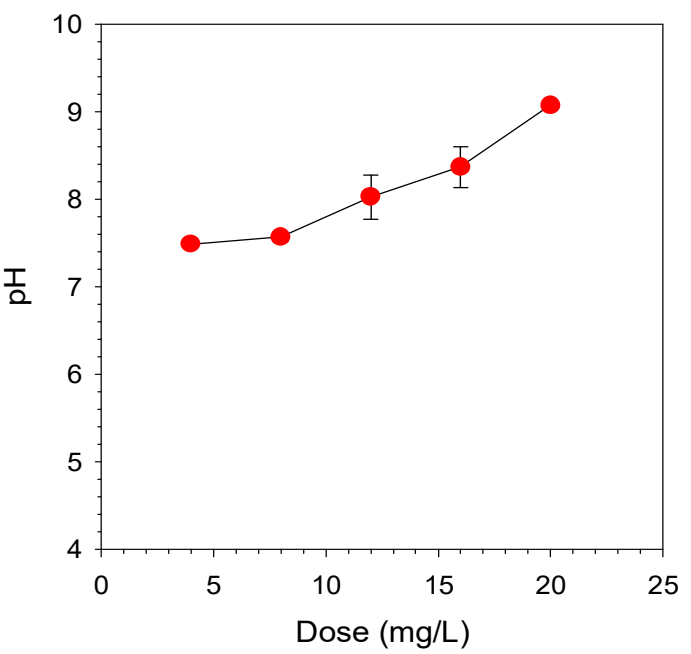

Gambar 2 Pengaruh penambahan kapur terhadap $\mathrm{pH}$ 


\section{Pengaruh Dosis Tawas Terhadap pH}

Pengolahan konvensional yang terdiri dari penetralan, koagulasi-flokulasi dan filtrasi. Pada tahap koagulasi-flokulasi, performa dioptimalkan pada penyisihan asam humat konsentrasi tinggi. Adapun koagulan yang digunakan adalah aluminum sulfat atau tawas yang murah dan mudah didapatkan. Koagulan ini terbukti dapat menyisihkan warna, kandungan logam dan bahan organik. Akan tetapi tidak dapat menyisihkan TDS ataupun garam. sehingga kombinasi dilakukan menggunakan filtrasi.

Air rawa asin yang diolah memiliki nilai $\mathrm{pH}$ yang mendekati 6 sehingga perlu dilakukan proses pengapuran. Alasan lain perlunya dilakukan proses pengapuran dikarenakan $\mathrm{pH}$ air rawa asin akan turun ketika diolah pada proses koagulasi-flokulasi. Proses koagulasi-flokulasi juga akan berjalan optimum jika dilakukan pada $\mathrm{pH}$ 6. Selain nilai $\mathrm{pH}$, nilai TDS dan konduktivitas air rawa asin turut meningkat setelah proses pengapuran dengan dosis kapur yaitu $20 \mathrm{mg} / \mathrm{L}$.

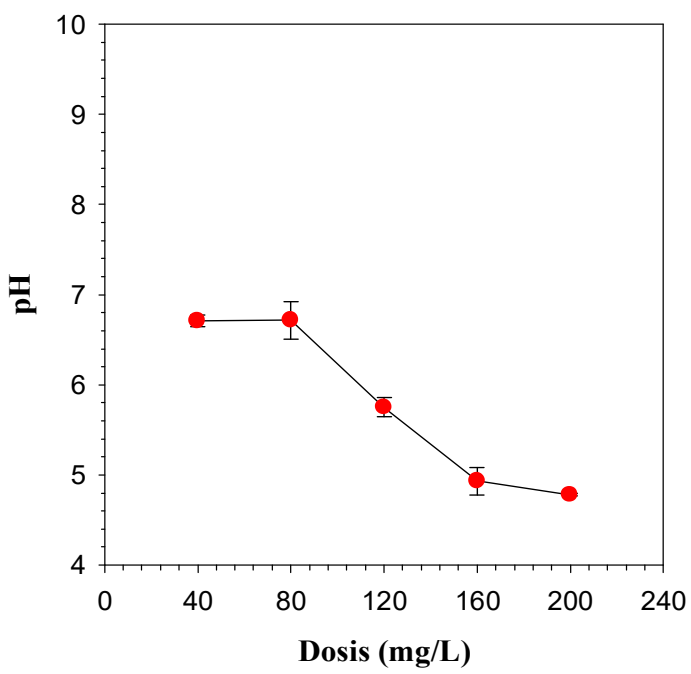

Gambar 3 Pengaruh penambahan tawas terhadap $\mathrm{pH}$

Pengaruh dosis tawas terhadap $\mathrm{pH}$ dapat dilihat pada Gambar 3. Gambar menunjukkan penambahan tawas dapat mengurangi $\mathrm{pH}$ dikarenakan lepasnya hidrogen pada saat pengadukan cepat dan lambat (Ntwampe et al., 2013). Dosis yang dipakai pada proyek ini yaitu sekitar $120 \mathrm{mg} / \mathrm{L}$ karena air yang dihasilkan lebih jernih.

\section{Pengaruh zeolit dan silika terhadap konduktivitas}

Pada filter ini, digunakan bahan utama yaitu pasir silika yang berperan dalam menahan garam untuk ikut ke air olahan. Teknologi ini juga tergolong konvensional, mudah dan murah. Dengan adanya kombinasi proses ini, setiap kontaminan dalam air rawa asin dapat dikurangi dengan baik. Kemudahan dalam pembuatan hingga pengoperasian teknologi, murah dan mudah diperoleh baik material ataupun peralatan serta perawatannya menjadi keunggulan pada invensi ini. Gambar 4 menunjukkan konduktivitas dengan variasi tebal lapisan zeolit atau silika. Hasil ini memperlihatkan efektivitas zeolit yang lebih tinggi dalam menyisihkan garam air rawa asin. Zeolit dapat menyisihkan kandungan garam sampai 95,38\%.

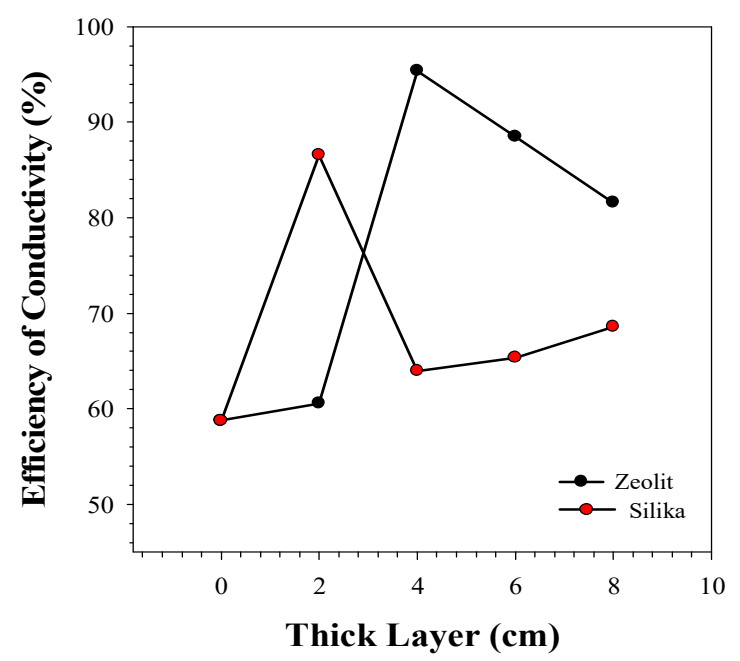

Gambar 4 Penyisihan konduktivitas antara zeolite dan silika

\section{Pengaruh zeolit dan silika terhadap TDS}

Perbandingan antara penggunaan zeolit dan silika dalam menyisihkan TDS dalam berbagai variasi ketebalan dapat terlihat pada Gambar 5. Gambar tersebut menunjukkan efektivitas lebih tinggi dalam menyisihkan TDS dengan menggunakan zeolit yaitu sekitar 95\%. TDS yang dihasilkan telah memenuhi baku mutu PERMENKES No 492 Tahun 2010 yaitu $500 \mathrm{mg} / \mathrm{L}$.

Ini bisa terjadi karena zeolit memiliki sifat sebagai saringan molekuler dan adsorben, karena struktur zeolit berongga sehingga zeolit mampu menyerap sejumlah besar molekul yang lebih kecil atau sesuai dengan ukuran rongga (Purwoto \& Nugroho, 2013). Selain itu, penambahan zeolite sendiri, juga dapat meingkatkan $\mathrm{pH}$ karena zeolit sendiri memiliki muatan negatif dan pori-pori terisi $\mathrm{K}, \mathrm{Na}, \mathrm{Mg}, \mathrm{Ca}$ dan $\mathrm{H} 2 \mathrm{O}$. Muatan ini menyebabkan adanya pertukaran ion dan pelepasan air (Arista Rahayu, 2015).

Selain zeolite, arang yang merupakan bahan lapisan filter yang juga berfungsi dalam menyisihkan TDS (Majid \& Santjoko, 2019). Arang aktif berasal dari tempurung kelapa sebagai lapisan filtrasi juga dapat dalam mengurangi kandungan TDS (Ratnoji \& Singh, 2014). Selain itu, Ca dan Mg yang menyebabkan kesadahan air dapat direjeksi oleh arang aktif (Rahmadhani \& Sari, 2014).

Tahap akhir yang merupakan kunci dari penghilangan konsnetrasi garam pada air rawa asin adalah filtrasi. Proses filtrasi pada invensi ini menggunakan silika yang mampu menurunkan salinitas air. Selain itu micro-floc dan sisa padatan terlarut yang tidak dapat terendapkan pada tahap koagulasi-flokulasi dapat disaring melalui proses filtrasi. 
Untuk mendapatkan hasil yang optimal, ketebalan dan ukuran dari lapisan media filter sangat menentukan. Umumnya, lapisan dasar media filter berukuran lebih besar daripada lapisan paling atas. Hal ini berfungsi untuk menahan padatan tersuspensi diatas lapisan media filter.

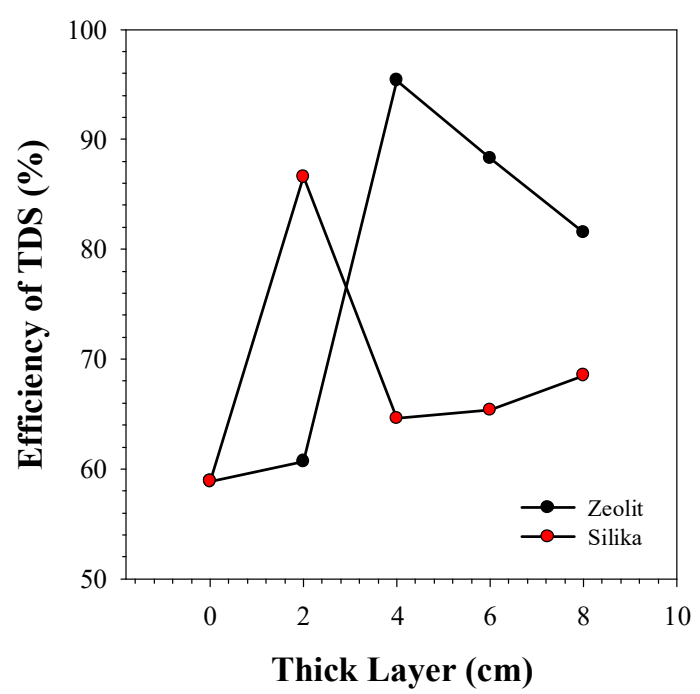

Gambar 5 Penyisihan TDS antara zeolit dan silika

Hasil air secara fisik dalam pengolahan ASA RAMI tiap prosesnya lebih rinci terdapat pada Gambar 6. Gambar tersebut memperlihatkan air yang semula kuning dan kecoklatan berubah menjadi bening setelah melalui proses netralisasi dan koagulasi. Pada proses pengadukan koagulasi atau penambahan tawas akan terbentuk flok. Pengendapan atau sedimentasi dilakukan untuk membuat flok mengendap sehingga air yang dihasilkan menjadi jernih.

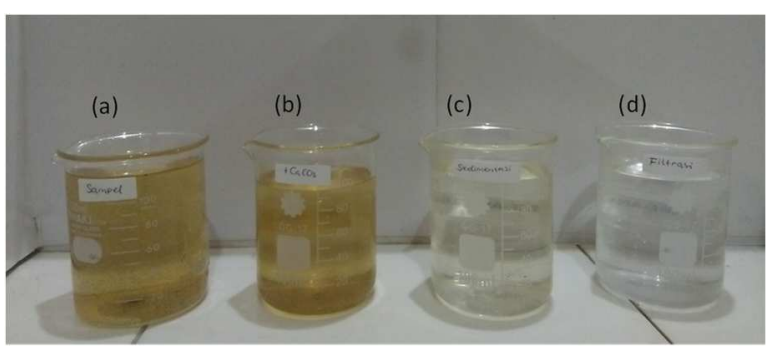

Gambar 6 (a) Air rawa asin sebelum diolah (b) setelah netralisasi (c) setelah koagulasi (d) setelah filtrasi menggunakan zeolite

Filtrasi adalah proses pemisahan padatan dari fluida (cairan atau gas) yang membuatnya menggunakan media berpori atau bahan berpori lainnya sebanyak mungkin untuk menghilangkan padatan tersuspensi dan koloid (Rahman, 2007). Selain mengurangi padatan, filtrasi juga dapat mengurangi kandungan bakteri, menghilangkan warna, rasa, bau, zat besi dan mangan (Poerwadio et al., 2004). Media utama yang menjadi focus dalam menghilangkan garam disini adalah zeolit.

\section{Sosialisasi}

Lokasi sosialisasi berlangsung di kantor lurah desa Muara Halayung, Kecamatan Beruntung Baru, Kabupaten Banjar. Instalasi ini dibuat di depan tempat fasilitas umum di desa Muara Halayung, kecamatan Beruntung Baru, Kabupaten Banjar. Masyarakat terlihat antusias mendengarkan sosialisasi cara membuat filtrasi yang bisa diterapkan di rumah penduduk sendiri.

Instalasi pilot project alat filtrasi air rawa asin di Desa Muara Halayung, Kab. Banjar-Kalsel dapat dilihat pada Gambar 7. Kapasitas pengolahan air rawa asin yang dibangun sebesar 600 Liter. Hasil kualitas air rawa asin setelah dilakukan filtrasi di lapangan disajikan pada Tabel 2.

Semua parameter baik TDS, pH dan konduktivitas air rawa asin setelah proses filtrasi mengalami penurunan seperti yang ditunjukkan pada Tabel 2. Nilai pH air rawa asin menjadi netral sekitar 7,23 sesuai baku mutu yang ditetapkan. Hasil tersebut terjadi akibat keberadaan material zeolite dan arang pada alat filtrasi. Selain itu penambahan kapur pada proses netralisasi juga berperan penting dalam meningkatkan nilai $\mathrm{pH}$ air rawa asin.

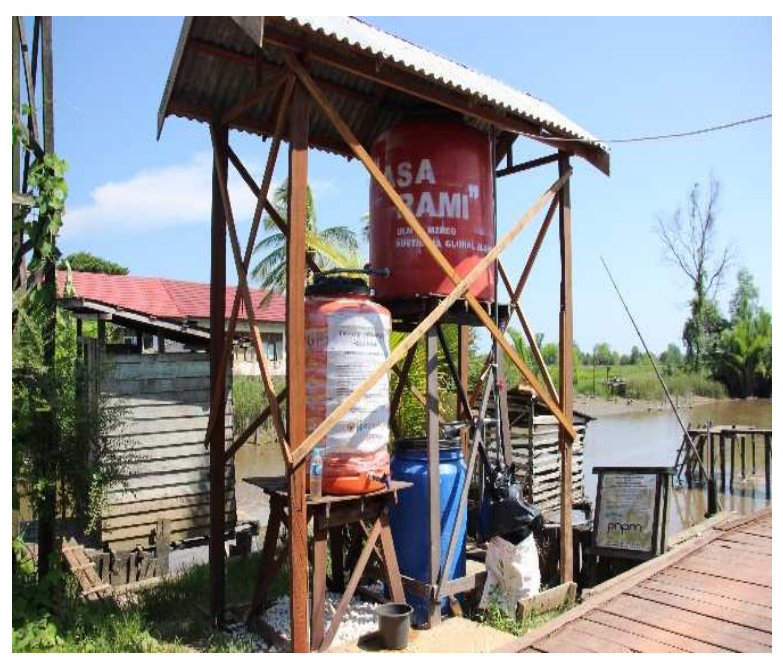

Gambar 7 Alat Filtrasi Air Rawa Asin

Tabel 2. Kualitas air rawa asin setelah proses filtrasi

\begin{tabular}{lcccc}
\hline \multirow{2}{*}{ Parameter } & Satuan & $\begin{array}{c}\text { Air rawa sebelum } \\
\text { diolah }\end{array}$ & $\begin{array}{c}\text { Air rawa sesudah } \\
\text { diolah }\end{array}$ & Baku mutu \\
\hline TDS & $\mathrm{mg} / \mathrm{L}$ & 6640 & 60,6 & 500 \\
$\mathrm{pH}$ & - & 6,41 & 7,23 & $6,5-8,5$ \\
Konduktivitas & $\mu \mathrm{S} / \mathrm{cm}$ & 13270 & 1152 & - \\
\hline
\end{tabular}


Parameter TDS juga mengalami penurunan hingga $>90$ \% (Tabel 2). Ratnoji and Singh (2014) melaporkan bahwa filtrasi konvensional menggunakan pasir sebagai media filternya dapat menyisihkan TDS dan meningkatkan nilai $\mathrm{pH}$. Hasil kualitas air rawa asin setelah filtrasi untuk parameter konduktivitas juga mengalami penurunan yang signifikan hingga lebih dari $90 \%$.

\section{Kesimpulan}

Alat filtrasi air rawa asin Mandiri (ASA RAMI) berhasil mengolah air rawa asin menjadi air bersih sehingga memenuhi baku mutu TDS, dan $\mathrm{pH}$ menurut PERMENKES No 492 Tahun 2010 serta baik dalam menyisihkan kandungan garam hingga $95 \%$.

\section{Ucapan Terimakasih}

Ucapan terimakasih ditujukan kepada Australian Awards melalui Australia Global Alumni tahun 20182019, Universiti Teknologi Petronas (UTP), Malaysia dan University of Sydney-Australia.

\section{Referensi}

Abhijeet, K. (2014). thesis, National Institute of Technology Rourkerla, India.

Al-Anber, M., \& Al-Anber, Z. A. (2008). Utilization of natural zeolite as ion-exchange and sorbent material in the removal of iron. Desalination, 225(1): 70-81. doi: https://doi.org/10.1016/i.desal.2007.07.006

Arista Rahayu, M. M., Ian Yulianti. (2015). Pengaruh Perubahan Massa Zeolit Terhadap Kadar Ph Limbah Pabrik Gula Melalui Media Filtrasi. Jurnal Fisika, 5(2)

Bacon, S., Culkin, F., Higgs, N. \& Ridout, P. (2007). Journal of Atmospheric and Oceanic Technology 24, 1785-1799.

Duan, J., Cao, X., Chen, C., Shi, D., Li, G. \& Mulcahy, D. (2012). Journal of Environmental Sciences 24, 1609-1615.

EPA (1995). Water Treatment Manuals Filtration.

Islam, R., Faysal, S., Amin, M., Juliana, F., Islam, M., Alam, J., .. Corresponding. (2017). Assessment of $\mathrm{pH}$ and Total Dissolved Substances (TDS) in the Commercially Available Bottled Drinking Water. 6: 35-40. doi: 10.9790/1959-0605093540

Jarvis, P., Sharp, E., Pidou, M., Molinder, R., Parsons, S. A. \& Jefferson, B. (2012). Water research 46, 4179-4187.

Kilic, S., Toprak, G. \& Ozdemir, E. (2016). International Journal of Mineral Processing 147, 1-9.

Maheshwari, R. (2006). Journal of Hazardous materials 137, 456-463.

Mahmud \& Mu'min, B. (2011). Lambung Mangkurat University.

Mahmud, Notodarmojo, S., Padmi, T. \& Soewondo, P. (2012). Info-Teknik 13, 28 - 37.

Majid, F., \& Santjoko, H. (2019). Pasir, Zeolit Dan Arang Aktif Sebagai Media Filtrasi Untuk Menurunkan Kekeruhan, Tds Dan E-Coli Air Sungai Selokan Mataram Yogyakarta. Poltekkes Kemenkes Yogyakarta.
Mariana, Z. T. \& Mahbub, M. (2015). Prosiding Seminar Nasional "Strategi Pemanfaatan Lahan Rawa dalam mendukung Kedaulatan Pangan Nasional".

Matilainen, A., Vepsalainen, M. \& Sillanpaa, M. (2010). Adv Colloid Interface Sci 159, 189-197.

Naswir, M. (2015). Asio Journal of Aanalytical Chemistry 1, 38-42.

Ntwampe, I. O., Hildebrandt, D. \& Glasser, D. (2013). Environmental Chemistry and Ecotoxicicology 5, 7-16.

Othman, A., Sulaiman, A. \& Sulaiman, S. K. (2017). AIP Conference Proceedings 1847, 040001.

Pivokonsky, M., Naceradska, J., Brabenec, T., Novotna, K., Baresova, M. \& Janda, V. (2015). Water research 84, 278285.

Poerwadio, A. D., Masduqi, A. \& FTSP-ITS, J. T. L. (2004). Jurnal Purifikasi 5, 169-174.

Purwoto, S. \& Nugroho, W. (2013). WAKTU 11, 47-59.

Rahman, Z. N. (2007).

Ratnoji, S. S. \& Singh, N. (2014). International Journal of Renewable Energy and Environmental Engineering 02, 14.

Santiago, O., Walsh, K., Kele, B., Gardner, E. \& Chapman, J. (2016). SpringerPlus 5, 571.

Zhao, Y., Gao, B., Zhang, G., Qi, Q., Wang, Y., Phuntsho, S., Kim, J.-H., Shon, H., Yue, Q. \& Li, Q. (2014). Separation and Purification Technology 130, 19-27.

Rahmadhani, \& Sari, D. (2014). Perbedaan Keefektifan Media Filter Zeolit Dengan Arang Aktif Dalam Menurunkan Kadar Kesadahan Air Sumur Di Desa Kismoyoso Ngemplak Boyolali. Universitas Muhammadiyah Surakarta.

Ratnoji, S. S., \& Singh, N. (2014). A Study of Coconut Shell Activated Carbon for Filtration And Its Comparison with Sand Filtration. International Journal of Renewable Energy and Environmental Engineering, 02(03): 14. Removal Natural Organic Matter (NOM) in Peat Water: Final Report ITSF Science and Technology Research Grant. Banjarbaru: Lambung Mangkurat University.

Ntwampe, I.O., Hildebrandt, D., \& Glasser, D. (2013). The Effect of Mixing on the Treatment of Paint Wastewater with $\mathrm{Fe} 3+$ and $\mathrm{Al} 3+$ Salts. Environmental Chemistry and Ecotoxicicology, Vol. 5, Issue 1, 7-16.

Poerwadio, A.D., Masduqi, A., FTSP-ITS, J.T.L. (2004). Penurunan Kadar Besi Oleh Media Zeolit Alam Ponorogo Secara Kontinyu Iron Removal By Natural Zeolite Of Ponorogo In Continuous Flow. Jurnal Purifikasi, Vol. 5, Issue 4, 169-174.

Purwoto, S., \& Nugroho, W. (2013). Removal Klorida, TDS dan Besi Pada Air Payau Melalui Penukar Ion dan Filtrasi Campuran Zeolit Aktif Dengan Karbon Aktif. WAKTU, Vol. 11, Issue 1, 47-59.

Rahman, Z.N. (2007). Pengaruh Variasi Tebal Media Filter Pasir, Zeolit, dan Kerikil dalam Menurunkan Kadar Kekeruhan dan TSS Pada Air Permukaan" Studi Kasus Air Selokan Mataram" 
Widiastuti, N., Wu, H., Ang, H. M., \& Zhang, D. (2011).

Removal of ammonium from greywater using natural zeolite. Desalination, 277(1): 15-23. 